\title{
A Case Study of Heavy Rain in Owase Area
}

\author{
By Takao Takeda, Noriaki Moriyama and Yasunobu Iwasaka \\ Water Research Institute, Nagoya University, Nagoya \\ (Manuscript received 5 June 1975, in revised form 24 November 1975)
}

\begin{abstract}
A case study is made for heavy rain which occurred in the area around Owase in the Kii Peninsula from the 9th to the 11th of September, 1971, using data from autographic raingauges with the aid of PPI radar photographs and the time variations of drop-size distribution and electric field intensity measured at Owase. Results of analysis show that travelling cumulonimbi produced heavy rain in Owase area, as if rainfall from it were amplified there, on account of the interaction with surrounding precipitating clouds of low top which formed only around Owase and in which the contribution of raindrops of 1 to $2 \mathrm{~mm}$ in diameter to rainfall intensity was very large. It can be inferred that very efficient mechanism of rainfall formation was realized in Owase area as a result of the modification of cumulonimbus due to orographic effect. Mechanism of orographic enhancement of rainfall is discussed. Further it is pointed out that during the period of heaviest rain electric field intensity has the time variation of long time scale which does not reflect the passage of individual cumulonimbus travelling from the south with the interval of two to four hours successively.
\end{abstract}

\section{Introduction}

Generally the horizontal distribution of rainfall is much dependent upon topography and rainfall amount has a tendency to be enhanced in the mountain range. In the western parts of the British Isles orographic effects cause heavy rainfall in the warm sectors of depression and Douglas and Glasspoole (1947) stated that the heaviest orographic rainfalls are associated with strong south-west to west winds in the warm sector. In the southeastern part of the Kii Peninsula in Japan (specially in the area around Owase) we have very often orographic rain in the situation of east to south-east wind.

Although mesoscale structure of heavy rainfall and the features of mesoscale disturbances associated with it have been studied by many authors (Matsumoto and Akiyama, 1969, 1970; Matsumoto, Ninomiya and Yoshizumi, 1971; Tatehira, 1968), progress toward a physical understanding of orographic heavy rain has been rather slow. Sawyer (1956) made a model for rainfall over the British Isles under the highly simplified assumption that the air is lifted by orography to the same extent at all levels. Sarker (1966) also presented a dynamical model for orographic rainfall, assuming a saturated atmosphere with pseudo-adiabatic lapse rate. Browning (1974) and Browning, Hill and Pardoe (1974) stated, in the case study of rainfall around the south Wales hills in a winter time warm sector, that precipitation was generated by orographic ascent in the middle levels far upwind of the hills and some of the precipitation seeded lowlevel orographic cloud over the hills. Their studies suggest that the hills might be able to generate their own seeds in certain circumstances and the occurrence of heavy warm sector rainfall over the hills appears to have been favoured by the existence of middle level potential instability.

In the rainfall associated with typhoon Vera it was shown by Staff Members of Tokyo University $(1969,1970)$ that the interaction between orographic rain and convective rain of typhoon rainbands was important for the enhancement of rainfall amount in the mountain range. Sakakibara and Takeda (1973) developed the study of Staff Members of Tokyo University quantitatively. They stated that in the rainfall of typhoon 7002 over the Kii Peninsula the rainfall caused by the traverse of a disturbance is subject to amplification process which would be 
dependent upon the topographic features around each station. They inferred that the orographic amplification of rainfall would be a result of the increase in the concentration of small raindrops not detected efficiently by a radar or the capture of many water drops existing at low levels by falling raindrops.

Most of heavy rains found in the mountain district would be due to the formation of the system which enhances the rainfall by orographic effect. In this paper a case study is made for heavy rain in Owase area where we have often orographic rain and the mechanism of orographic enhancement of rainfall is discussed.

\section{Brief description of rainfall and data}

As seen in Fig. 1, heavy rain occurred in the southeastern part of the Kii Peninsula from the 9 th to the 11th of September in 197.1. Total rainfall from 3.00 LST on the 9th to $3.00 \mathrm{LST}$ on the 11th exceeds $1,000 \mathrm{~mm}$ in the narrow area around Owase, while it is less than $200 \mathrm{~mm}$ at Hinodedake which is only $20 \mathrm{~km}$ distant from Owase. It is to be noted that heavy rain was found only to the southeastern side of mountains and rainfall does not reach $100 \mathrm{~mm}$ in most part of the peninsula.

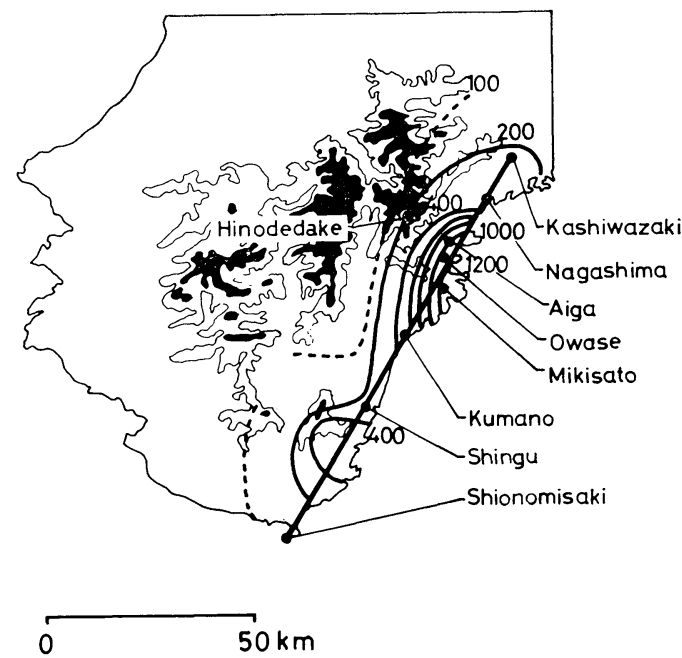

Fig. 1 Total rainfall from $3.00 \mathrm{LST}$ on the 9 th to $3.00 \mathrm{LST}$ on the $11 \mathrm{th}$, 1971, in the Kii Peninsula.

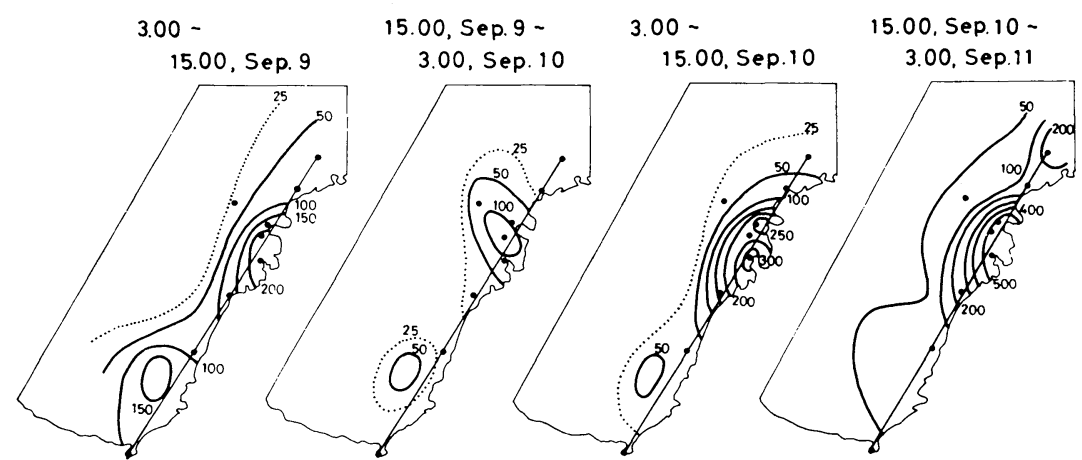

Fig. 2 Rainfall in each period of 12 hours in the southeastern part of the peninsula.

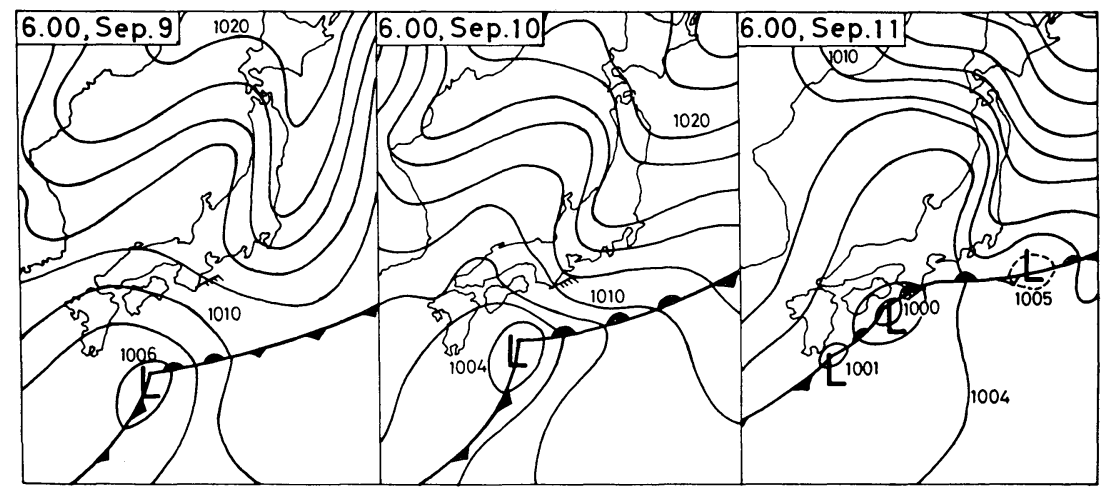

Fig. 3 Synoptic patterns at 6.00 on the 9 th, the 10 th and the 11 th of September. 
Fig. 2 shows that rainfall is concentrated in the southeastern part of the peninsula in any period of 12 hours. We can see some differences between precipitation patterns of early and later periods. Although heavy rain occurred in both Owase area and Shingu area with the amount over $100 \mathrm{~mm}$ in the first period of 12 hours, it is found only in the Owase area in the last period and its amount exceeds $500 \mathrm{~mm}$ in the central region. In this paper detailed analysis is made mainly for the heavy rain of the last period.

Upper air soundings at Shionomisaki indicate that east to south-east wind was prevalent at low levels both on the 9th and on the 10th in accordance with depression approaching the peninsula (Fig. 3). It has been said that we often experience heavy rain around Owase in this meteorological situation. South wind found between $800 \mathrm{mb}$ and $650 \mathrm{mb}$ levels until $21.00 \mathrm{LST}$ on the 10th became prevalent also at lower levels after that time.

Analysis was made using data from autographic raingauges at eight points located along the southeastern seashore line of the peninsula, which are shown in Fig. 1, with the aid of PPI radar photographs taken every $10 \mathrm{~min}$ at Nagoya Meteorological Observatory which is about $140 \mathrm{~km}$ northeastward from Owase. Further the time variations of atmospheric electric field and the size distribution of raindrops measured on the ground at Owase were used in the analyses. Chemical component of rainwater and solid particles in it were also measured at Owase. They will be described in another paper.

\section{Analyses of precipitation and radar echo patterns}

Fig. 4 is the time variations of rainfall intensity averaged for 20 minutes at Owase and at Hinodedake. The intensity of heaviest rainfall at Owase reaches $100 \mathrm{~mm} / \mathrm{hr}$. Rain at Hinodedake indicates the variation much different from that at Owase even qualitatively though the distance between both stations is only $20 \mathrm{~km}$. Its variation is more gentle and it is much weaker with the intensity less than $20 \mathrm{~mm} / \mathrm{hr}$ through 48 hours (note that the scale of ordinate is different between upper and lower figures). We can see that the two types of variations are prevalent in the case of Owase-one has the time scale longer than 12 hours and another has the scale of two to four hours. Specially the latter is remarkable after 10.00 on the 10th. These features can be also found out in other stations along the seashore.

The features in time variations of long time scale at eight stations are made clear by processing serial data at each station through a low-pass filter having the response over 0.5 for the variation of period longer than 10 hours. They are shown in Fig. 5. Three remarkable peaks can be seen at Owase and neighbouring

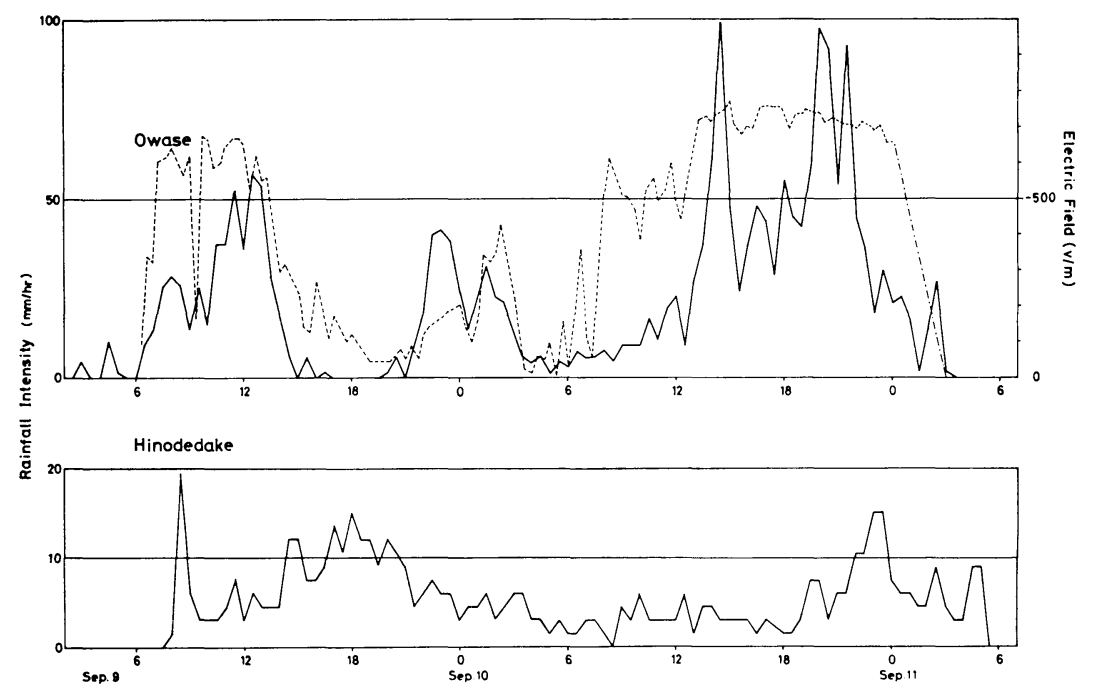

Fig. 4 Time variations of rainfall intensity at Owase and Hinodedake stations. Dashed line indicates the variation of electric field intensity measured at Owase. 

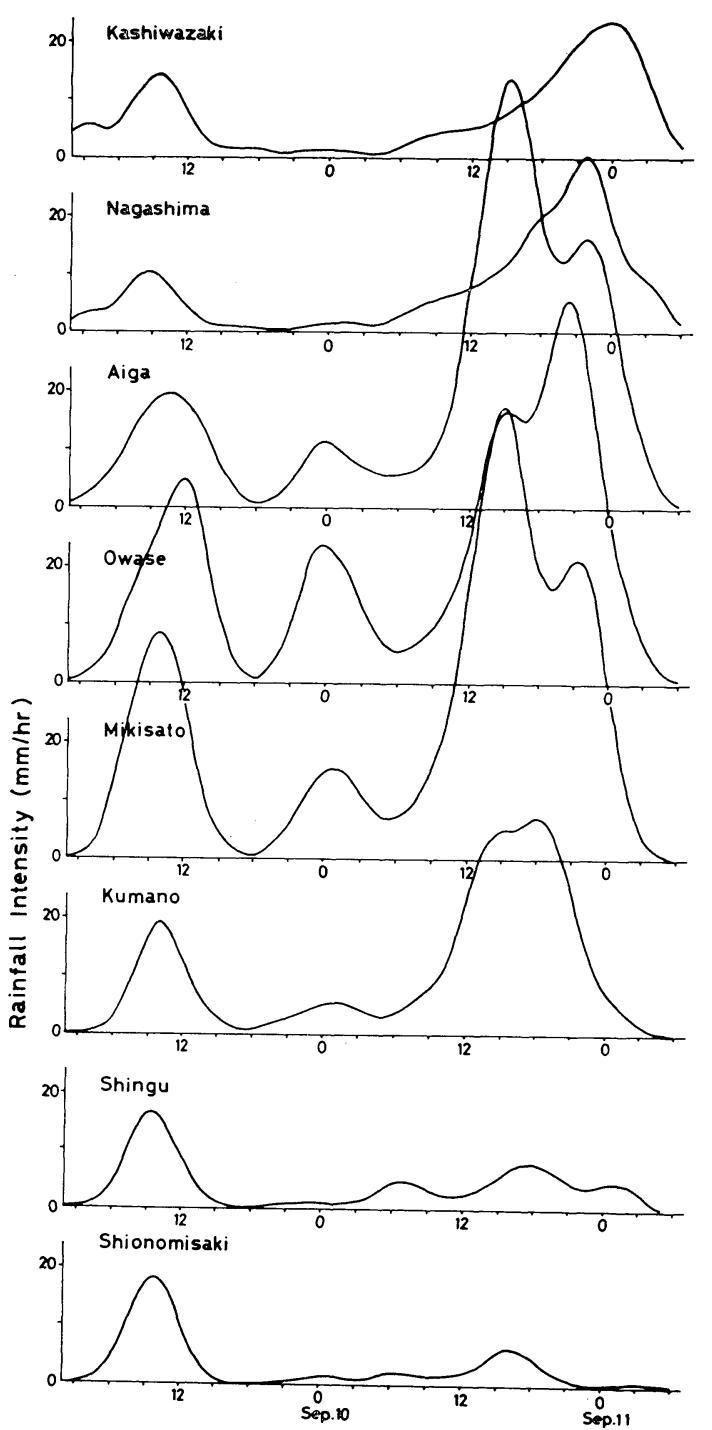

Fig. 5 Time variations of rainfall intensity of long time scale at eight stations along the line shown in Fig. 1.

stations. It is to be noted that the second peak is not found out at stations distant from Owase. The fact that both the first and the third peaks have larger values around Owase than at other stations suggests the existence of amplification process, by which rain-making disturbances can produce larger amount of rainfall in the area around Owase (it might be possible to make the same interpretation on the second peak).

Similar amplification can be seen also in serial data of rainfall intensity processed by a bandpass filter which has the response over 0.5 for the time variation of two to four hours. Fig. 6 is the time cross section of these serial data along the seashore line during the period of 11.00 on the 10 th to 4.00 on the 11 th. Black and white points indicate the existence of positive and negative peak values of filtered serial data at each station, respectively. Hatched areas mean that rain is stronger in the time corresponding to the area than before and after that time. We will use the word of "stronger" rain for the rain in the hatched area, which does not mean stronger rain in the spatial distribution of rainfall. The movements of "stronger" rain toward Owase are clear specially from 17.00 on the 10 th to 1.00 on the 11 th, and their speed of SSW-NNIE component is 20 to $30 \mathrm{~km} / \mathrm{hr}$. It is interesting that the amplitude of time variation of filtered serial data is very large around Owase. This fact implies that rainfall caused by disturbances moving northwards is intensified around Owase. As inferred from the figure, travelling disturbances would have the interval of several tens kilometers in the south of Owase. Further it should be noted that the movements of "stronger" rain (disturbances) in the northern side of Owase are considerably different from that in the southern side. Disturbances would have been subject to some modification in travelling over Owase.

Echo patterns of PPI radar of Nagoya Meteorological Observatory indicate that each "stronger" rain appears at Owase when a group of cellular echoes moving northward reached there, as shown in Fig. 7. The top-height of strong cellular echo over Owase at 20.00 exceeds $10 \mathrm{~km}$. The rain-making disturbances the movements of which are shown in Fig. 6, would be a group of cumulonimbi. It is to be noted in Fig. 7 that an echo of a type other than travelling cellular ones exists continuously over Owase area and cellular echoes enter into the echo, which is $25 \mathrm{~km} \times 10 \mathrm{~km}$ in horizontal size at 11.43. This can be seen more clearly in time cross section of Fig. 8 in which the existence of radar echoes along the line shown in Fig. 1 is represented by hatched area. The areas of vertical stripes are the same as hatched areas in Fig. 6. It is seen that cellular echoes travelling from the south go into the echo staying over Owase in succession. The movements of cellular echoes and "stronger" rain areas are in good agreement. Disagreement seen during the period of 22.00 to 24.00 occurred because two peaks included in original time variation of rainfall intensity were not able to be separated by adopt- 


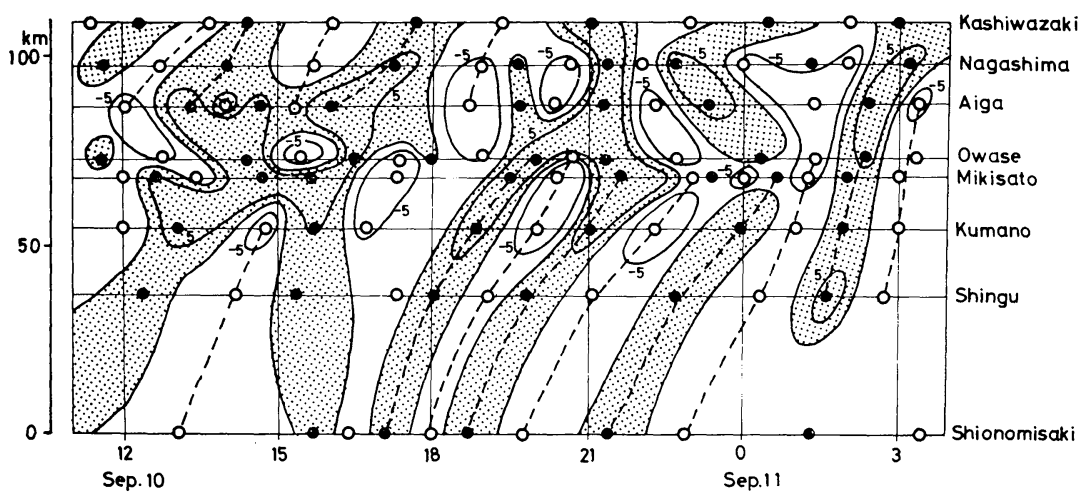

Fig. 6 Time cross section of filtered rainfall intensity along the line shown in Fig. 1. Black and white points indicate the existence of positive and negative peak values of the intensity, respectively.
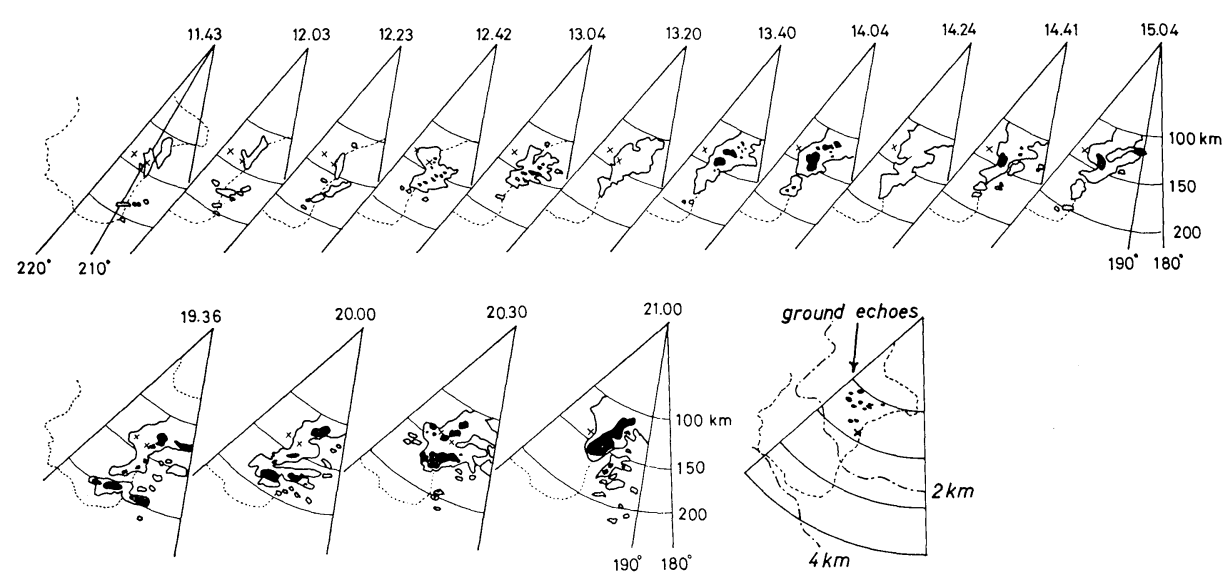

Fig. 7 PPI radar echo patterns observed on Sep. 10 at Nagoya Meteorological Observatory. Echoes stronger than gain level 4 (corresponding to $4 \mathrm{~mm} / \mathrm{hr}$ roughly) are represented by black areas. Contours of radar shadow and ground echoes are shown in the last picture.

ed band-pass filter. We can say that a group of cumulonimbi produced heavier rain than in surrounding area as if their rainfall were amplified, when they entered into precipitating cloud which existed continuously over Owase area.

\section{Size distribution of raindrops measured at Owase}

The size distribution of raindrops measured at Owase seems to reflect the process of rainfall mentioned above. Ordinate in Fig. 9 is the rainfall intensity given by raindrops of each size range, which is averaged for 20 minutes. It is very interesting that the variations during the period of 13.00 to 24.00 on the 10th and the period of 7.00 to 11.00 on the 9th are much different from that from 20.00 on the 9 th to 13.00 on the 10th. In the former periods raindrops of each size range which are larger than $2 \mathrm{~mm}$ in diameter indicate the time variation of good correlation, while the raindrops of 1 to $2 \mathrm{~mm}$ show the variation in the opposite sense to larger drops-that is, their number density decreases when the number of larger drops increases (vice versa). The number density of larger drops reaches its peak values when cellular echoes arrived at Owase.

It would be reasonable to say that two types of rainfall appeared at Owase in the former periods alternatively. Rainfall of one type (I) was found when cellular echoes were over Owase and many large drops are included in it. It 

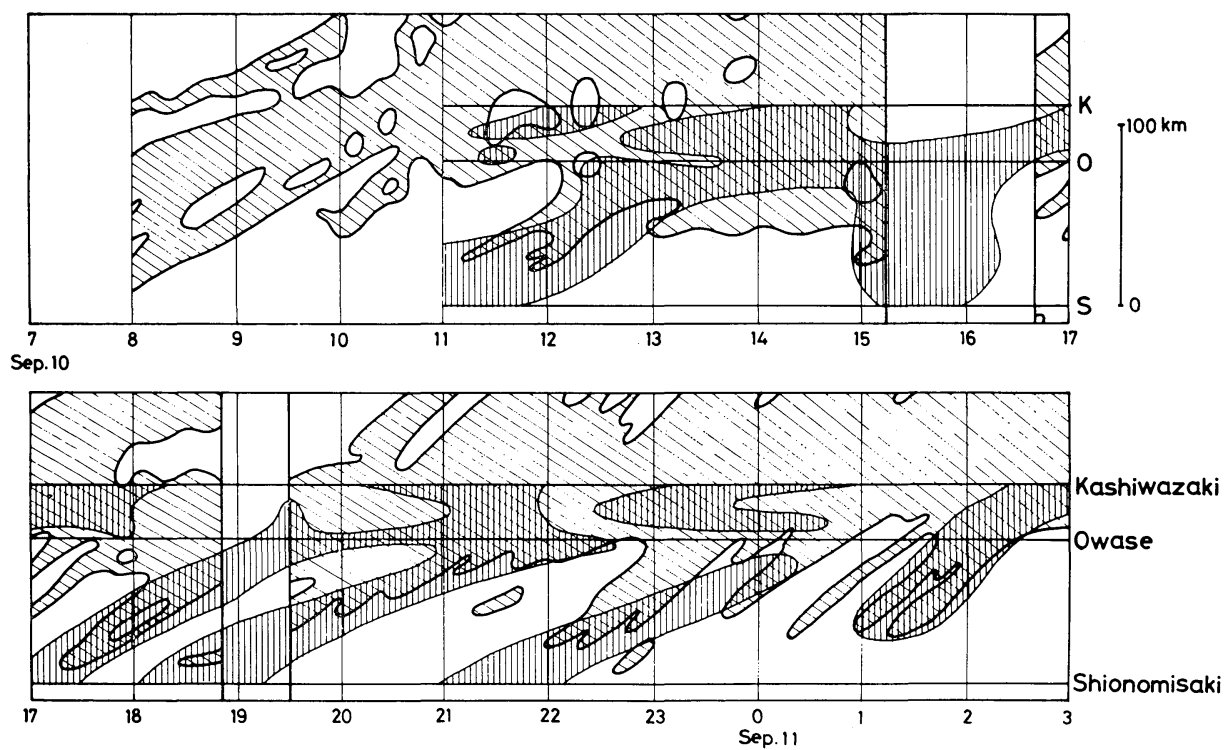

Fig. 8 Time cross sections of radar echo (hatched area) and filtered rainfall intensity (area of vertical stripes) along the line shown in Fig. 1.

would originate from cumulonimbus. Rainfall of tribution to total rainfall intensity.

the other type (II) occurred between travelling cumulonimbi and the number of small drops ( 1 to $2 \mathrm{~mm}$ ) in it is more than in type $\mathrm{I}$, though Rainfall from 20.00 on the 9th to 13.00 on the 10th found only around Owase has the rain is lighter and there are less large drops in This suggests that clouds existing over Owase comparison with type I. In this type raindrops in this period can be inferred to have radar of 1 to $2 \mathrm{~m} m$ have the remarkably large con- echoes of the same type as ones observed be-

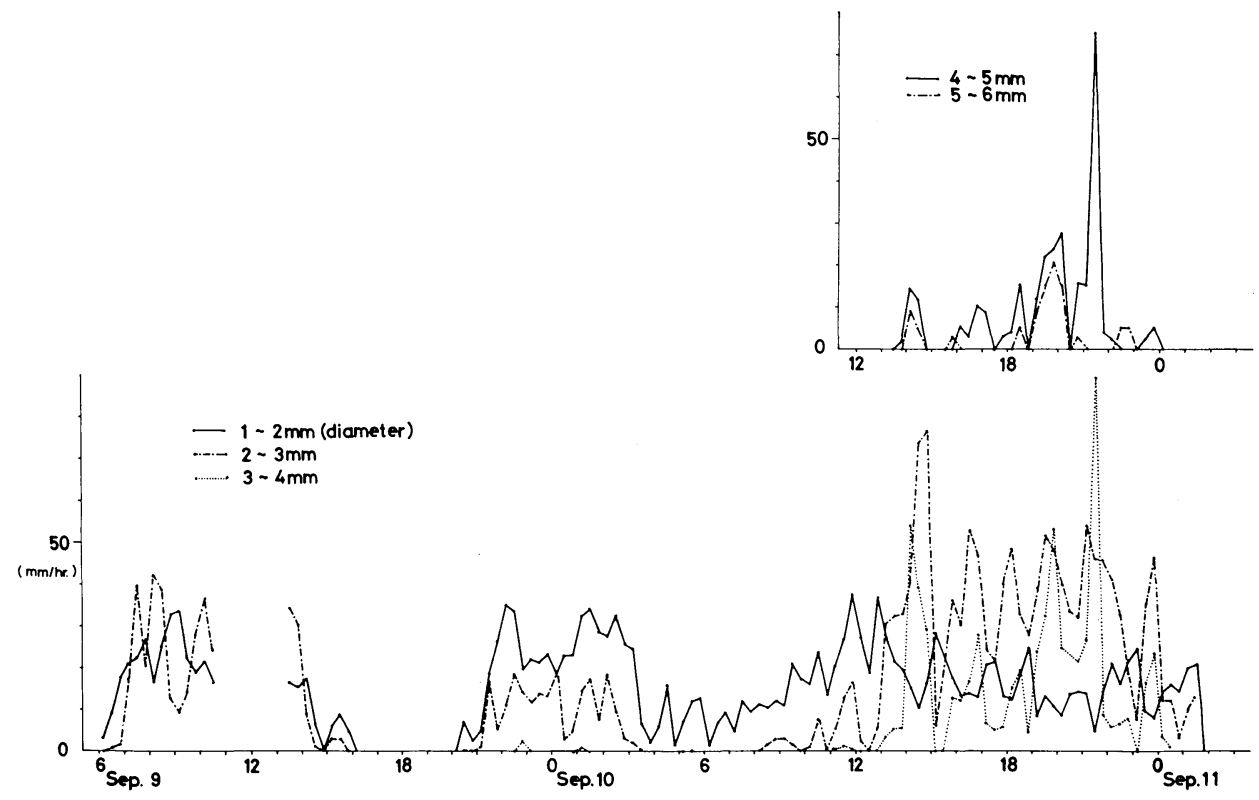

Fig. 9 Time variation of rainfall intensity given by water drops of each size range measured at Owase. 


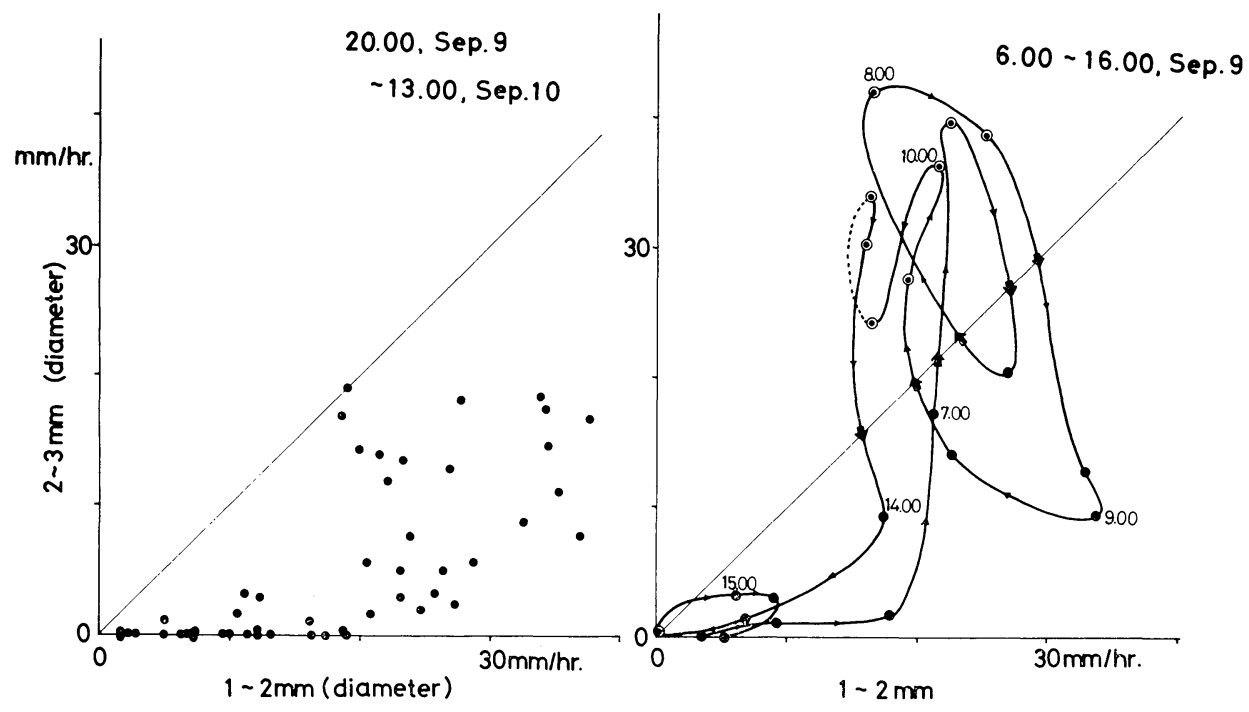

Fig. 10 Relationships between rainfall intensities given by drops of 1 to $2 \mathrm{~mm}$ and 2 to $3 \mathrm{~mm}$ in diameter.

tween cellular echoes before and after the period, though unfortunately there were no data on radar echoes in the period. As shown in the left part of Fig. 10 raindrops of 1 to $2 \mathrm{~mm}$ show rainfall intensity much larger than drops of 2 to 3 $\mathrm{mm}$. The right part of the figure indicates a relationship between both drops in the rain from 6.00 to 16.00 on the 9th. The alternative occurrence of rainfall of two types can be seen from it. When a group of cumulonimbi reached Owase and rain became heavier, the number density of drops of 1 to $2 \mathrm{~mm}$ decreased. During the period of heavy rain (from 13.00 to 24.00 on the 10th) the alternative occurrence of two types appears more drastically than shown in Fig. 10. It can be inferred from radar observations that rainfall found between travelling cumulonimbi is produced by low cloud of stratiform, the fine structure of which is not clear. Probably it would consist of many small convective clouds in such a way as pointed out by Yanagisawa et al. (1974).

\section{Atmospheric electric field at Owase}

Atmospheric electric field measured at Owase which is shown by dashed line in Fig. 4 suggests another important process of heavy rain. Before 12.00 on the 10th the time variation of field intensity with the period of a few hours is in good agreement with that of rainfall intensity-negative peak values of field are observed when the extreme values of rainfall intensity appear. It can be inferred that the individual precipitating convective cloud has negative charges in its lower parts and field intensity changes with time in accordance with the passage of the cloud. After 12.00 on the 10th, however, we can see only the variation of long time scale which is similar with that of rainfall shown in Fig. 5 The fine variation of field intensity is considerably different from rainfall intensity. These features were made more clearly by processing the serial data of field intensity through the same low-pass and band-pass filters as adopted for rainfall (the result of processing is not shown here). It is concluded that during the period of heavy rain we were not able to find out the time change of field intensity related to the passage of individual cumulonimbus (cellular echo), which is reflected on the size distribution of raindrops as well as rainfall intensity.

If individual cumulonimbus contains an electric dipole with negative charge in its lower part, these results would be due to following processes - the spatial interval of travelling cumulonimbi becomes narrower with approaching to Owase or cumulonimbi are combined and modified into a larger convective system although some features of individual cumulonimbus are maintained in the system. Fig. 11 is the result of numerical computation on the time variation of field intensity which will be realized by the passage of two dipoles with horizontal interval of $10 \mathrm{~km}$ and moving velocity of $5 \mathrm{~m} / \mathrm{s}$. The variation 


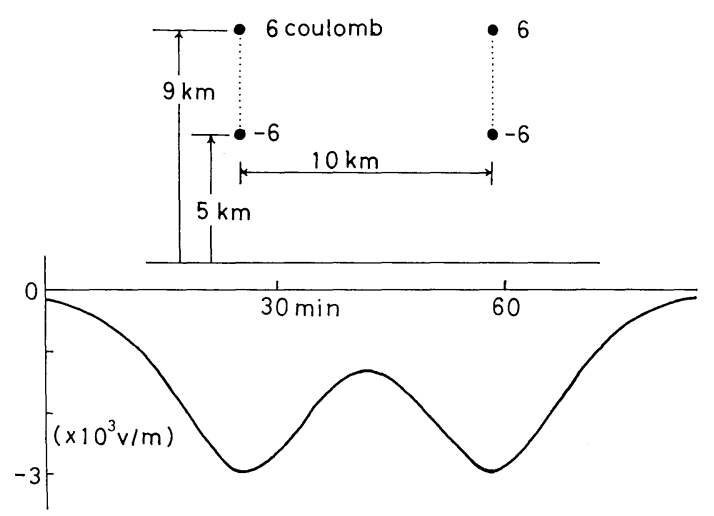

Fig. 11 Time variation of electric field intensity realized by travelling two electric dipoles the velocity of which is assumed to be $5 \mathrm{~m} / \mathrm{s}$.

caused by each dipole is detected clearly in the figure. The smoothed variation such as seen during the period of heavy rain would be able to be realized only by dipoles which are adjacent more closely or which exist at much higher levels. Fig. 6 indicates that travelling cumulonimbi were at intervals of several tens kilometers in the south of Owase, but their behaviors varied around Owase. At present it could not be made clear which of two processes mentioned above took place. In order to study the electrical structure of clouds associated with heavy rain, further measurements of electric field and charges of precipitation particles in cloud as well as on the ground will be necessary.

\section{Summary and discussions}

The facts described in previous chapters indicate that cumulonimbi moving from the south produced heavy rain around Owase on account of the interaction with stratiform clouds of low top, which will be of warm-rain type formed only near Owase and in which the contribution of raindrops of 1 to $2 \mathrm{~mm}$ in diameter to rainfall intensity is very large. It can be said that large precipitating convective cloud was modified with approaching to Owase due to orographic effect and low stratiform cloud formed around it. The result of these processes would be observed by radar as phenomena that cellular echoes enter into echo existing continuously around Owase. Yanagisawa et al. (1974) showed from radar observation of Typhoon 7123 rainfall at Owase that many cumuli the echo tops of which were lower than $3 \mathrm{~km}$ were distributed densely around Owase and they played a significant role in the maintenance of strong rain in this region. Fujiwara et al. (1974) also suggested in the analyses of showers formed in Owase area along a stationary front that the structure of raincloud composed of tower clouds and low level clouds was important in the development

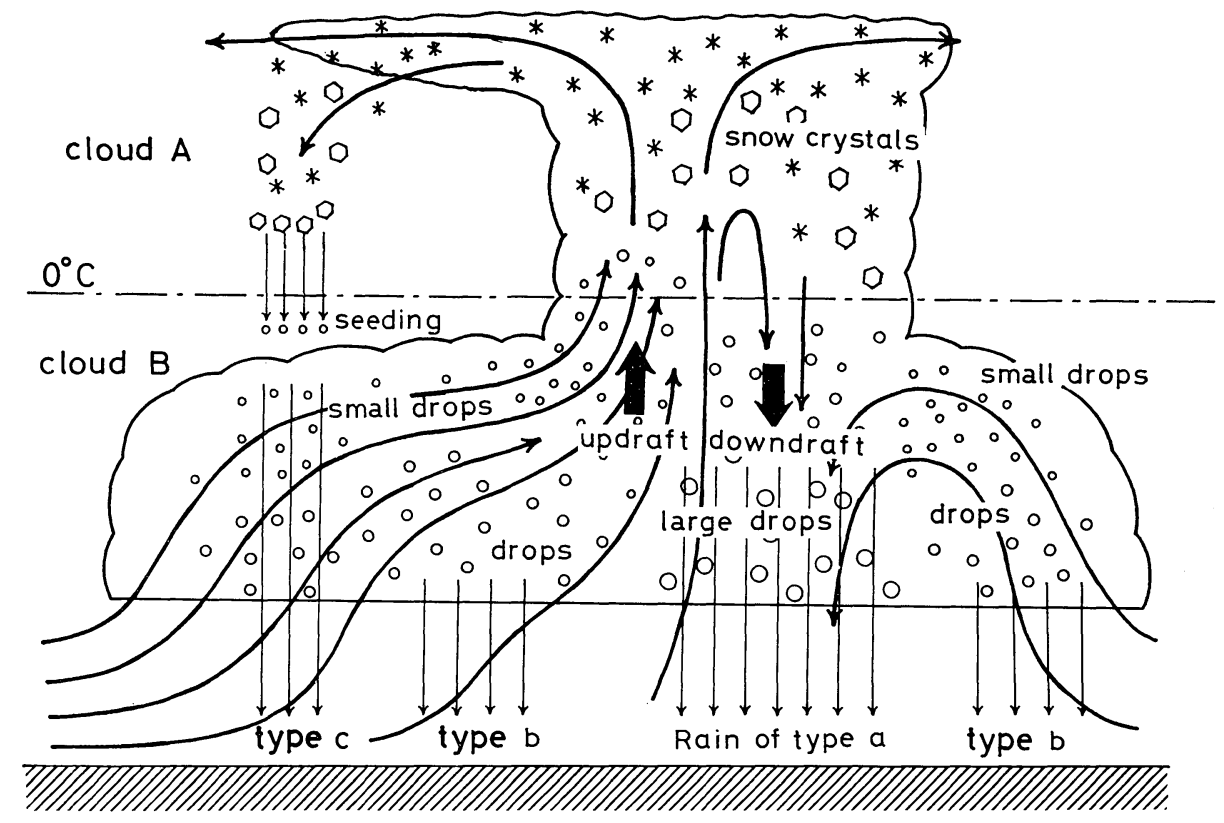

Fig. 12 Schematic representation of rainfall formation in the area around Owase. 
of heavy rain.

Clouds of low top described in this paper, including clouds found during the period of 20.00 on the 9 th to 13.00 on the 10 th, as well as those in papers by Yanagisawa et al. and Fujiwara et al. would be of the same kind as ones which are formed very often around this area when east wind is prevalent at low levels and which have been said to cause larger amount of rainfall than expected from radar observation of Nagoya Meteorological Observatory (Murayama and Fukatsu, 1969). As stated before, upper air soundings at Shionomisaki indicate that east to southeast wind was prevalent at low levels both on the 9th and on the 10th.

The amplification of rainfall by orographic effect, which was pointed out by Sakakibara and Takeda (1973), would be associated with processes that water drops which should have fallen from low stratiform clouds can grow larger drops in cumulonimbus or they can be coagulated by larger drops in it and that even small water drops which could not become raindrops neither in stratiform cloud nor in cumulonimbus can grow large sufficiently on account of the interaction of both clouds. Very efficient mechanism of rainfall formation can be said to be made around this region.

The process of rainfall amplification cloud be inferred as follows. It is represented schematically in Fig. 12. Rains of types $a$ and $b$ are from modified cumulonimbus (cloud A) and from only stratiform cloud of low top mentioned above (cloud B), respectively. They have the size distributions of type I and type II stated in chapter 4 , respectively, and the former rain would include drops much larger than the latter. Modification of cumulonimbus approaching Owase area is naturally related to meso-scale horizontal convergence caused by orographic effect around Owase. While cumulonimbus itself develops, stratiform clouds form in its surroundings as a result of horizontal convergence. The amount of condensed water increases in cumulonimbus. Further, condensed water stored as small drops of large number density in stratiform clouds flow into not only the updraft but also the downdraft of cumulonimbus with entrained air. It will be possible that the mixing of water drops of two groups which are quite different in the type of size distribution means the increase of colloidal instability and it makes very efficient process of rainfall formation. Possibility of amplification of rainfall due to the interaction of both clouds would be dependent upon whether the supply of water from surrounding area is enough or not and whether the microphysical properties of both clouds such as the size distribution of water drops, which is closely associated with the spectrum of condensation nuclei, are favourable or not.

It is possible that cumulonimbus causes the seeding of ice particles or water drops formed by their melting into surrounding low clouds and that rainfall from low clouds is enhanced (rain of type $c$ in Fig. 12). Although we could not find out facts suggesting the seeding process in the case described in this paper, the process would be important in the formation of heavy rain. Bright band will be detected by radar observations in rain of this type. As described in chapter 1, Browning, Hill and Pardoe (1974) pointed out the importance of seeding process, which is somewhat different from one represented in Fig. 12, in orographic heavy rain. The process will be a problem to be studied quantitatively.

\section{Acknowledgements}

The authors wish to express their hearty thanks to staff members of Nagoya Meteorological Observatory for useful discussions and for the supply of radar photographs. The authors are also indebted to staff members of Owase Meteorological Station for offering convenience to their observations. This study was supported by a Fund for Scientific Research from the Ministry of Education.

\section{References}

Browning, K. A., 1974: Mesoscale structure of rain systems in the British Isles. J. Meteor. Soc. Japan, 52, 314-327.

- F. F. Hill, and C.W. Pardoe, 1974: Structure and mechanism of precipitation and the effects of orography in a wintertime warm sector, Quart. J. Roy. Meteor. Soc., 100, 309330.

Douglas, C. K. M., and J. Glasspoole, 1947: Meteorological conditions in heavy orographic rainfall. Quart. J. Roy. Meteor. Soc., 73, 11-38.

Fujiwara, M., J. Aoyagi; J. Shiino and T. Yanase, 1974: On the cloud structure related to heavy rainfall as revealed by radar. Papers in Meteor. and Geophys., 25, 24-50.

Matsumoto, S., and T. Akiyama, 1969: Some characteristic features of the heavy rainfalls observed over the western Japan on July 9, 1967. Part 1: Mesoscale structure and short 
period pulsation. J. Meteor. Soc. Japan, 4\%, Sakakibara, H., and T. Takeda, 1973: Modification $255-266$. of Typhoon 7002 rainfall by orographic effect. J. Meteor. Soc. Japan, 51, 155-167.

ances and related rainfall cells embedded in the "Baiu front," with a proposal on the role of convective momentum transfer. J. Meteor. Soc. Japan, 48, 91-102.

K. Ninomiya and S. Yoshizumi, 1971: Characteristic features of "Baiu" front associated with heavy rainfall. J. Meteor. Soc. Japan, 49, 267-281.

Murayama, N., and H. Fukatsu, 1969: Limit of detection of rainfall over Owase by Nagoya Weather Radar. Tokan Gijutsu News, 10, 2025, in Japanese.

Sarker, R. P., 1966: A dynamical model of orographic rainfall. Mon. Wea. Rev., 94, 555-572.

, 1967: Some modifications in a dynamical model of orographic rainfall. Mon. Wea. Rev., 95, 673-684.
Sawyer, J. S., 1956: The physical and dynamical problems of orographic rain. Weather, 11, 375381.

Staff Members, Division of Meteorology, Tokyo University, 1969: Precipitation bands of Typhoon Vera in 1959. Part 1. J. Meteor. Soc. Japan, 4\%, 298-309.

- 1970 : Precipitation bands of Typhoon Vera in 1959. Part 2. J. Meteor. Soc. Japan, 48, 103-117.

Tatehira, R., 1968: A study of rainband. Geophys. Mag., 34, 115-137.

Yanagisawa, Z., J. Aoyagi and N. Kamibayashi, 1974: Radar analysis on the precipitation around Owase. Papers in Meteor. and Geophys., 25, 51-80.

\title{
尾鷲地域の豪雨の case study
}

\author{
武田喬男・森山憲昭・岩坂泰信 \\ 名古屋大学 水圈科学研究所
}

1971年9月9日から11日にかけて尾鷲地域に起った豪雨の解析を行った。用いた資料は，雨量自記紙，PPIレーダ 一写真及び尾鴠で観測した雨滴粒度分布，大気電場である。解析の結果は，北上してくる積乱雲が，尾鷲附近で背の 低い降水雲との相互作用の結果，それからの降雨が増幅されたかのように豪雨をもたらしたことを示している。この 背の低い降水雲は尾鷲の附近にの久形成され，この雲からの雨では直径 1 2 $\mathrm{mm}$ の雨滴の降雨強度への貢献度が非 常に大きかった。地形の効果による積乱雲の変質の結果, 尾韵地域では非常に効率の良い降水形成過程がつくられて いると推測される。また，豪雨の最盛期には，大気電場は，2４時間毎に通過する個々の積乱雲に対応する時間変 動を示さず，より長い時間スケールの変動のみを示した。 